International Journal of Instruction e-ISSN: 1308-1470 • www.e-iji.net

Article submission code: 20190506211637

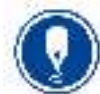

January $2021 \bullet$ Vol.14, No.1

p-ISSN: 1694-609X

pp. 253-264

Received: 06/05/2019

Revision: 17/06/2020
Accepted: 07/07/2020

OnlineFirst:18/10/2020

\title{
Classroom Life Perception Scale: A Scale Development Study ${ }^{1}$
}

\section{Burak Ayçiçek}

Dr., Tokat Gaziosmanpaşa University, Turkey, aycicekburak@gmail.com

\section{Tuğba Yanpar Yelken}

Prof., Mersin University, Turkey, tyanpar@gmail.com

The aim of the study is to develop a scale named Classroom Life Perception Scale (CLPS) for determining the classroom life perceptions of the students toward lessons. The proposal scale, composed of 44 items, was applied to 2 study groups. The group of Exploratory Factor Analysis that aims to determine the psychometric properties especially the construct validity and reliability of CLPS consisted of 462 9th, 10th, 11th and 12th grade students. The group of Confirmatory Factor Analysis that aims to find out whether the factor structure demonstrated by CLPS was confirmed or not consisted of 282 9th, 10th, 11th and 12th grade students. As a result of the analyses, it has been determined that the scale consists of 28 items and it has a structure composed of three factors. The study showed that CLPS is a valid and reliable tool. Using CLPS with other data collection tools on classroom life perceptions of students will contribute to literature.

Keywords: classroom, classroom life perception, scale development, validity, reliability

\section{INTRODUCTION}

The classroom is the most important social environment that affects students' academic success. For this reason, the characteristics of this social environment where learning takes place directly affect success. In general, it is stated that classroom environments can be positive, supportive or normative (Baek \& Choi, 2002). Correspondingly, the classroom is quite an important environment not only for cognitive but also for emotional processes. The emotional experiences of the students directly affect their learning skills, commitment to the school and career choices. The factors affecting students' emotional states need to be adressed in detail in order to improve students' emotional state and eliminate the obstacles caused by the teacher (Trezise \& Reeve, 2014).

\footnotetext{
${ }^{1}$ This study is a part of a doctoral dissertation titled "An investigation of technology-enhanced flipped classroom model applications effect on high school students' classroom engagement, academic achievement and classroom life perceptions in teaching English" under the supervision of Prof. Dr. Tuğba Yanpar Yelken.

Citation: Ayçiçek, B., \& Yanpar Yelken, T. (2021). Classroom Life Perception Scale: A Scale Development Study. International Journal of Instruction, 14(1), 253-264. https://doi.org/10.29333/iji.2021.14115a
} 
Shaughnessy (1991) has stated that factors such as communication, harmony, clarity, integrity, commitment, interest, cooperation, courage, autonomy, risk-taking and internal motivation are required to be included in the classroom. In classroom environment, factors such as close relations between friends, sense of trust and belonging, feeling valued and precious, sense of understandability, a supportive and fair interaction environment, teacher's being sensitive to student's feelings, social and emotional connection between teacher and student, respect, the teacher's approach to students as their friends to understand create perception of classroom life. In order to create such a learning environment, students should be encouraged to rely on their own decisions and student creativity should be supported (Cole et al., 1999). For a positive classroom environment, it is necessary that the teachers make clear what they expect from the students, the students are able to take their responsibilities, and the teacher explains clearly what the rules are in the classroom (Wilson-Fleming and Wilson-Younger, 2012). Moreover, teachers need to establish positive relationships with students and find solutions to inappropriate classroom behaviors. The interaction between students and teachers is important in terms of creating desired behavioral changes in students (Banks, 2014).

The classroom environment in which students can easily express their thoughts, beliefs and feelings about themselves, other individuals and the actions taking place in the classroom contributes positively to the students' learning process (Schunk and Meece, 1992). Therefore, whether the classroom environment is warm and inviting or not, the availability of all areas in the classroom for students and the suitability of this environment for educational purposes are significant (Bucholz \& Sheffler, 2009). Students learn better if they think that the classroom environment is positive and supportive (Dorman, Aldridge and Fraser, 2006). A positive classroom environment is an environment where students feel belonging to the class, are encouraged in the face of difficulties, take risks, trust other individuals and ask questions. In such a learning environment, the development of social skills that will help students succeed is easier (Bucholz \& Sheffler, 2009).

Students' opinions, thoughts, perceptions and beliefs about all actions taken in the classroom provide direct information to teachers about the effectiveness of those actions (Darby, 1991). Therefore, it is necessary to determine the students' perceptions about the classroom environment, the teacher and the learning process in order to understand what is really happening in the classroom. (Walberg \& Haertel, 1980). Classroom life includes students' perceptions about the classroom environment, teachers and other students in the classroom and the teaching process. However, teacher behavior is not perceived in the same way by all students in the classroom (Darby, 1991). Teacher behaviors are directly influential in directing students' actions within the classroom and in this way their own learning processes. In addition, not only teachers affect students in the learning environment; it is observed that students influence their teacher and other friends (Doyle, 1977). In this sense, classroom life refers to a complex structure including the relationship between teachers and students in the classroom, cognitive and social actions taken in the classroom (Shimahara, 1998); the opinions, attitudes and expectations of teachers and students about what is happening in the classroom (Ellison 
et al., 2000) and the degree of support and interest that students receive from their teachers in the classroom environment (Reynolds and Miller, 2003).

As a result of an extensive literature survey, there are almost no developing scale studies that measure high school students' classroom life perception towards English lesson. Therefore, this study will be unique at home and abroad as well as making contributions to the literature field. Within the context of this study, it has been aimed to develop a "Classroom Life Perception Scale" (CLPS) for high school students.

For this purpose, the research questions below are addressed.

1. What are the exploratory and confirmatory factor analysis results of the "Classroom Life Perception Scale" (CLPS)?

2. What are the reliability test results of the "Classroom Life Perception Scale" (CLPS)?

\section{METHOD}

\section{Research Goal}

The purpose of this study is to develop a scale that determines the level of classroom life perceptions of high school students in addition to describing its pyschometric features (validity and reliability).

\section{Sample and Data Collection}

This study is a descriptive study that aims to develop a scale for determining the level of classroom life perceptions of high school students towards English lesson. The psychometric properties (validity-reliability) and development processes of this scale were investigated by researchers.

\section{Scale Development Group}

The scale development group of this research consists of two groups. In order to determine the psychometric properties of the scale, data were collected from two different groups that are Exploratory Factor Analysis and Reliability Group and Confirmatory Factor Analysis Group. In this study, purposeful sampling was used as it was easily accessible to the researcher.

\section{Exploratory Factor Analysis and Reliability Group}

This group was used to determine the psychometric properties especially the construct validity and reliability of CLPS. The participants of this group were high school students going to schools in different districts of Hatay. This group consisted of 462 students. Of the students constituting the group, 218 (47\%) students were male and $244(53 \%)$ female. As for the distribution of the study group in terms of class variable, 126 students $(27 \%)$ were from 9th grade, $114(25 \%)$ from 10th grade, 121 (26\%) from 11th grade and $101(22 \%)$ from 12 th grade.

\section{Confirmatory Factor Analysis Group}

This group was used to discover whether the factor structure demonstrated by CLPS as a result of exploratory factor analysis was confirmed or not. The participants of this group were high school students going to schools in different districts of Hatay. This group consisted of 297 students. These districts have different level of income. This group 
consisted of 282 students. Of the students constituting the group, 128 (45\%) students were male and $154(55 \%)$ female. As for the distribution of the study group in terms of class variable, 72 students $(25 \%)$ were from 9th grade, 81 (29\%) from 10th grade, 68 $(24 \%)$ from 11 th grade and $61(22 \%)$ from 12 th grade.

\section{Scale Development Process}

It has been stated in the literature that the scale development process should have certain steps (Cohen \& Swerdlik, 2013; Crocker \& Algina, 1986; DeVellis, 2014; Şeker \& Gençdoğan, 2014). In this study, scale development steps are: 1) Determining the goal of the scale (determining the level of classroom life perceptions of the students; 2) Defining high school students from Hatay to apply the scale; 3) Determining the nature and scope of the properties (classroom life perception level) intended to be specified in the scale; 4) Deciding on the types of items in the scale in the context of the features intended to be specified (classroom life perception level); 5) Writing test items in the type of items determined; 6) Review of the items and forming a questionnaire; 7) Asking field experts' opinions about the legibility of the scale; 8) In accordance with the field experts' opinions, giving the scale its final form before the pilot application; 9) Scoring and analyzing the items; 10) Presentation of the psychometric properties of the scale (reliability and validity) at the end of the pilot application; 11) Forming the real scale based on the results obtained.

\section{Data Collection Instrument}

As a data collection instrument, "Classroom Life Perception Scale" was used in the study with the aim of determining the classroom life perception level of students towards English lesson. After the literature on "Classroom life perception" was reviewed, the scale was developed. Based on the information gathered from the review and expert opinions, the scale with 44 items was generated as a five point- Likert Scale Likert ranging from strongly disagree (1) through strongly agree (5). 16 items were extracted from the scale and 28 items were left as a result of the analysis. These 28 items provided a three factors structure for the scale. Items numbered 6 and 8 on the scale are reverse coded. These items are the ones that contradict with the term "classroom life perception".

The left items of the scale are the ones that develop classroom life perception and include the basic components of it. When items numbered 6 and 8 on the scale are reverse coded, all the items of the scale show a congruity. Getting high score from the scale shows that students have a high level of classroom life perception, whereas getting low score from the scale shows that they have a low level of classroom life perception.

\section{Analyzing of Data}

The data were analyzed by using analyzed using IBM-SPSS 22 and AMOS 22 software. In order to measure the validity and reliability of CLPS, Kaiser-Meyer-Olkin (KMO) test, Bartlett Sphericity test, Varimax rotation, Cronbach Alpha coefficient, and confirmatory factor analysis procedures were conducted (Büyüköztürk, 2013; Özdamar, 2013). 


\section{FINDINGS}

\section{Psychometric properties of CLPS (validity and reliability)}

Exploratory factor analysis was carried out to examine construct validity of CLPS. In order to determine the validity and reliability of CLPS, Kaiser-Meyer-Olkin (KMO) test, Bartlett Sphericity test, Varimax rotation, Cronbach alpha reliability coefficient, and confirmatory factor analysis were used (Büyüköztürk, 2013; Özdamar, 2013). Prior to factor analysis, item total correlations were calculated. Items numbered 7, 9, 10, 13, 14, $16,19,24,26,29,32,35,37,38,42$ and 44 were extracted from the scale because their correlation values were below 0,300 and so the values of these items lowly contribute to the phenomenon which will be explained by the scale. A total of 16 items were excluded from the scale. Psychometric properties about the left 28 items are summarized in Table 1.

Table 1

Exploratory Factor Analysis and the Results of Reliability Analysis

\begin{tabular}{|c|c|c|c|c|}
\hline \multirow{2}{*}{$\begin{array}{l}\text { Number of } \\
\text { Items }\end{array}$} & \multirow{2}{*}{$\begin{array}{l}\text { Item-Total } \\
\text { Correlation }\end{array}$} & \multicolumn{3}{|c|}{ Correlation Loading in Factor Analysis } \\
\hline & & Factor I & Factor II & Factor III \\
\hline M1 & 0,512 & 0,418 & & \\
\hline M2 & 0,633 & 0,457 & & \\
\hline M3 & 0,510 & 0,672 & & \\
\hline M4 & 0,673 & 0,732 & & \\
\hline M5. & 0,658 & 0,605 & & \\
\hline M6 & 0,563 & 0,540 & & \\
\hline M7 & 0,454 & 0,559 & & \\
\hline M8 & 0,610 & 0,518 & & \\
\hline M9 & 0,611 & 0,606 & & \\
\hline M10 & 0,699 & & 0,708 & \\
\hline M11 & 0,553 & & 0,635 & \\
\hline M12. & 0,664 & & 0,638 & \\
\hline M13 & 0,723 & & 0,416 & \\
\hline M14 & 0,667 & & 0,489 & \\
\hline M15 & 0,562 & & 0,596 & \\
\hline M16 & 0,663 & & 0,598 & \\
\hline M17 & 0,651 & & 0,479 & \\
\hline M18 & 0,444 & & & 0,558 \\
\hline M19 & 0,631 & & & 0,491 \\
\hline M20 & 0,612 & & & 0,692 \\
\hline M21 & 0,592 & & & 0,701 \\
\hline M22 & 0,622 & & & 0,562 \\
\hline M23 & 0,728 & & & 0,679 \\
\hline M24 & 0,501 & & & 0,714 \\
\hline M25 & 0,577 & & & 0,439 \\
\hline M26 & 0,570 & & & 0,668 \\
\hline M27 & 0,711 & & & 0,472 \\
\hline M28 & 0,423 & & & 0,583 \\
\hline \multicolumn{5}{|c|}{$\mathrm{KMO}=0,931$} \\
\hline \multicolumn{5}{|c|}{ Bartlett Sphericity $\left(X^{2}\right)=4118,715 ; \mathrm{df}=92, \mathrm{p}<0.01$} \\
\hline \multicolumn{5}{|c|}{ Variance Accounted for First Factor $=38,110 \%$} \\
\hline \multicolumn{5}{|c|}{ Variance Accounted for Second Factor $=23,599 \%$} \\
\hline \multicolumn{5}{|c|}{ Variance Accounted for Third Factor $=19,883 \%$} \\
\hline \multicolumn{5}{|c|}{ Variance Accounted for Three Factors $=81,592 \%$} \\
\hline Cronbach A & & & & \\
\hline
\end{tabular}


The construct validity of CLPS was determined by using principal component analysis. This analysis also includes Kaiser Meyer Olkin (KMO) and Bartlett Test, which were carried out to check the appropriateness of the data for factor analysis. As seen in Table 1 , KMO value was found to be 0.931 . This value should be at least over 0.50 . The obtained KMO value shows that the data set is appropriate for analysis. The Bartlett Test result was $\left.\left[\mathrm{X}^{2}=4118,715 ; \mathrm{df}=92, \mathrm{p}<0.01\right)\right]$. The significance value was found lower than 0.05 , which means factor analysis can be conducted. The results of exploratory factor analysis obtained show that item-total correlations are between 0,423 and 0,728 . The variances accounted for first, second and third factors are 38\%, \%23 and $19 \%$ respectively. The variance accounted for all three factors explained is $81 \%$ and this value is considered acceptable for the scale development studies in social sciences (Büyüköztürk, 2013).

In the explanatory factor analysis, Varimax rotation was used in order to determine whether the scale revealed any factor (Büyüköztürk, 2013; Özdamar, 2013). As a result of Varimax rotation, three factors were determined in the scale. The factors are about student feelings related to the classroom environment, student feelings related to the teacher and student feelings related to other students.

The factors in the scale were tested for reliability. The results were summarized in Table 2.

Table 2

Cronbach's Alpha Test Results for CLPS

\begin{tabular}{ll}
\hline Subdimensions & Cronbach Alpha \\
\hline Student Feelings Related to the Classroom Environment & 0,891 \\
Student Feelings Related to the Teacher & 0,818 \\
Student Feelings Related to Other Students & 0,789 \\
\hline
\end{tabular}




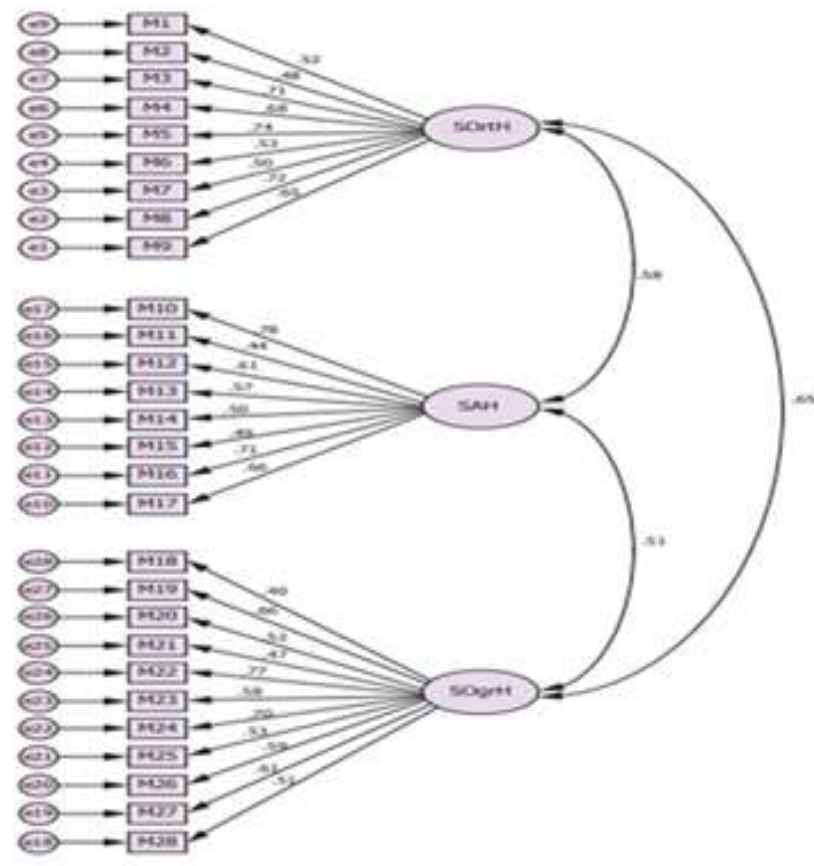

Figure 1

CLPS Confirmatory Factor Analysis Model (Standardized Values)

Chi-square and degree of freedom obtained from Confirmatory Factor Analysis (CFA) are $=97,01,(\mathrm{df}=53, \mathrm{p}<.01)$ and the ratio of $/ \mathrm{df}=1,83$ is obtained. That the ratio obtained from the selected samples is less than 3 indicates a perfect consistency (Joreskog and Sorbom, 1993; Sumer, 2000; Kline, 2005). Thus, it can be asserted that the consistency between the data set and the model found in CFA is perfect. The other known goodness of fit values obtained via CFA are summarized in Table 3.

Table 3

Goodness of Fit Values Obtained from CFA

\begin{tabular}{lllllll}
\hline$\chi^{2}$ & sd & $\chi^{2} / \mathrm{sd}$ & RMSEA & AGFI & RMR & CFI \\
\hline 97,01 & 53 & 1,83 & 0,056 & 0,92 & 0,062 & 0,99 \\
\hline
\end{tabular}

It can be said that one of the most commonly used goodness of fit indexes in CFA is RMSEA. In an CFA analysis, 0.05 or a lower value of RMSEA is an indicator of modeldata fit. Even so, it is also stated that this value can be acceptable up to 0.08 (Browne and Cudeck, 1993; Hu and Bentler, 1999; Simsek, 2007; Vieira, 2011). The RMSEA value in this study is 0.056 , which is considered acceptable. The AGFI value higher than 0.80 and the RMR lower than 0.10 can be considered acceptable values that indicate the model-data fit (Anderson \& Gerbing, 1984; Marsh, Balla \& McDonald, 1988). The result of CFA determines AGFI as 0.92 and RMR as 0.062. According to these results, 
it can be asserted that model-data fit is acceptable. The main aim of CFA is to identify the goodness of fit between a model and previously obtained data (Sumbuloglu \& Akdag, 2009). In this respect, it may be implied that one-factor structure of CLPS was confirmed.

\section{DISCUSSION}

The goal of this research is to develop a scale measuring the level of classroom life perceptions of high school students towards English lesson. Classroom life includes the students' perceptions about the classroom environment, teacher, other students in the classroom and the teaching process. As Darby (1991) said classroom life refers to social relations in the classroom, instructional process, physical structure, classroom management, affective factors such as attitude, perception and expectation. Classroom life perception expresses how much support and attention students receive from their teachers in the classroom. According to Fraser (1998), positive classroom environment affects students' achievement levels, behaviors, self-efficacy beliefs, and social and emotional development levels positively. Therefore, CLPS aims to evaluate the various characteristics and dimensions of the school environment, including the structure of the classroom.

The scale consists of three sub-dimensions. The first sub-dimension of the scale is student feelings related to the classroom environment. The classroom environment is the most important social environment that affects students' academic achievement. Therefore, the characteristics of this social environment in which learning takes place directly affect success. In general, it is stated that classroom environments can be positive, supportive or normative (Baek \& Choi, 2002). Accordingly, classroom environment is an environment where not only cognitive processes but also emotional processes are very important. Students' emotional experiences directly affect their learning skills, their commitment to school and career choices. (Trezise \& Reeve, 2014). Patrick and Ryan (2003) investigated the social environment in the classroom and how students were encouraged to interact with each other. In this context, the social structure in the classroom, teacher support, developing mutual respect and interacting with other individuals were discussed.

The second sub-dimension of the scale is student feelings related to other students. In the study conducted by Russell (2012), the effect of secondary school students' perceptions of the support they receive from their classmates on the social climate of the class and the social behaviors of the students were examined. As a result of the study, it was seen that there was a positive relationship between perceived social support and classroom behaviors.

The third sub-dimension of the scale is student feelings related to the teacher. Huang, Eslami and $\mathrm{Hu}$ (2010) investigated the relationship between teachers' support and foreign language learning anxiety. As a result of the study, it was found that academic support provided by the teacher was the most common variable related to the anxiety of learning a foreign language and that the anxiety of students decreased when they received more academic support from their teachers. 
Students learn better if they see the learning environment as positive and supportive. Such an environment encourages students. In addition, students are provided with learning opportunities in a positive classroom environment to contribute to the development of social skills (Young, 2014). Turner et al. (2002) found that if students perceive the classroom environment as a place that provides fun, personal and social support, students avoid less from academic tasks assigned to them. Talton and Simpson (1987), on the other hand, found that there was a significant and positive relationship between students' attitudes towards the classroom environment and their attitudes towards the course. In the light of this information, it can be said that classroom environment is an important variable in terms of learning process and students' opinions and feelings about the classroom environment affect learning process. Therefore, students' positive senses of the classroom environment can affect their efforts positively and provide the desired learning outcomes.

When the factors related to the scale are examined, it is seen that high school students' perceptions and beliefs about various factors in the classroom are emphasized. In this sense, students' perceptions of classroom life need to be investigated in order to create a more effective learning environment and using CLPS can be considered important in education settings. CLPS is developed for high school students, however the scale can be used for different school stages.

\section{CONCLUSION}

In this study, a scale that aims to determine the level of classroom life perceptions of students was developed. A total of 16 items were removed from the scale because their correlation values were low and some of these items failed to comply with the rule that each factor should consist of at least three items in a factor analysis, It was determined that the remaining 28 items form three factors in terms of the validity and reliability of the scale. The reliability value of the scale is above 0.93 . The results of exploratory factor analysis obtained show that item-total correlations are between 0,423 and 0,728 . The variances accounted for first, second and third factors are 38\%, \%23 and 19\% respectively. The variance accounted for all three factors explained is $81 \%$ and this value is considered acceptable for the scale development studies in social sciences. Three-factors structure model obtained as a result of exploratory factor analysis was also confirmed in confirmatory factor analysis. The factors are named as 'student feelings related to the classroom environment', 'student feelings related to the teacher' and 'student feelings related to other students'. In consideration of the findings, it can be said that the scale developed as a result of this study has necessary psychometric features such as reliability and validity and could be applied in further research.

\section{RECOMMENDATIONS}

In this study, it can be said that the desired sample sizes were reached for the scale development. Therefore, this scale can be used in other studies. In the field literature, there have been no developed scales or studies that aim to the level of classroom life perceptions of high school students. Therefore, using CLPS with other data collection 
tools will make contribute to literature. In addition, CLPS can also be applied to a broader audience as the application of the instrument.

\section{REFERENCES}

Anderson, J. C., \& Gerbing, D. W. (1984). The effect of sampling error on convergence, improper solutions, and goodness of fit indices for maximum likelihood confirmatory factor analysis. Psychometrika, 49, 155-173

Baek, S. G., \& Choi, H. J. (2002). The relationship between students' perceptions of classroom environment and their academic achievement in Korea. Asia Pacific Education Review, 3(1), 125-135.

Banks, T. (2014). Creating positive learning environments: Antecedent strategies for managing the classroom environment \& student behavior. Creative Education, 5, 519524.

Browne M. W., \& Cudeck R. (1993). Single sample cross-validation indexes for covariance structures. Multivariate Behavioral Research, (4)24, 445-55

Bucholz, J. L., \& Sheffler, J. L. (2009). Creating a warm and inclusive classroom environment: Planning for all children to feel welcome. Electronic Journal for Inclusive Education, 2(4), 1-13.

Büyüköztürk, Ş. (2013). Sosyal bilimler için veri analizi el kitabı (Handbook of data analysis for social sciences). Ankara: Pegem Akademi.

Cohen, R. J., \& Swerdlik, M. E. (2013). Psikolojik test ve değerlendirme, testler ve ölçmeye giriş (Psychological testing and assessment, an introduction of test and measurement) (Çev.Ed. Ezel Tavşancıl). Ankara: Nobel

Cole, D. G., Sugioka, H. L., \& Yamagata-Lynch, L. C. (1999). Supportive classroom environments for creativity in higher education. Journal of Creative Behavior, 33(4), 277-293.

Crocker, L., \& Algina, J. (1986). Introduction to classical and modern test theory. CBS Collage Publishers Company.

Darby, M. (1991). Student perceptions in a social studies classroom. Retrieved from https://ro.ecu.edu.au/theses_hons/249.

DeVellis, R. F. (2014). Ölçek geliştirme, kuram ve uygulamalar (Scale development, theory and applications) (Çev.Ed. Tarık Totan). Ankara: Nobel.

Dorman, J. P., Aldridge, J. M., \& Fraser, B. J. (2006). Using students' assessment of classroom environment to develop a typology of secondary school classrooms. International Education Journal, 7(7), 906-915.

Doyle, W. (1977). Paradigms for research on teacher effectiveness. Review of Research in Education, 5(1), 163-198. 
Ellison, C. M., Boykin, A. W., Towns, D. P., \& Stokes, A. (2000). Classroom cultural ecology: The dynamics of classroom life in schools serving low-income African American children. Washington, DC: Howard University, Center for Research on the Education of Students Placed at Risk.

Fraser, B. J. (1998). Classroom environment instruments: Development, validity, and applications. Learning Environments Research, 1, 7-33.

Hu L. T., \& Bentler P. M. (1999). Cut off criteria for fit indexes in covariance structure analysis: conventional criteria versus new alternatives. Structural Equation Modeling: A Multidisciplinary Journal, 6(1), 1-55.

Huang, S., Eslami, Z., \& Hu, R. J. S. (2010). The relationship between teacher and peer support and English-language learners' anxiety. English Language Teaching, 3(1), 3240 .

Jöreskog, K. G., \& Sörbom, D. (1993). Lisrel 8: Structural equation modeling with the simples' command language. Hillsdale: Erlbaum Associates Publishers

Kline, R. B. (2005). Principles and practice of structural equation modeling. New York: The Guilford Press.

Marsh, H. W., Balla, J. R., \& McDonald, R. P. (1988). Goodness-of-fit indices in confirmatory factor analysis: the effect of sample size. Psychological Bulletin, 103(3), 391-410.

Özdamar, K. (2013). Paket programlar ile istatistiksel veri analizi (Package programs and statistical data analysis), Eskişehir: Nisan.

Patrick, H., \& Ryan, A. M. (2003, March). Identifying adaptive classrooms: Analyses of measures of dimensions of the classroom social environment. Paper prepared for Positive Outcomes Conference. Retrieved from https://www.childtrends.org/wpcontent/uploads/2013/05/Child_Trends-2003_03_12_PD_PDConfPatRyan.pdf.

Reynolds, W. M., \& Miller, G. E. (2003). Current perspectives in educational psychology. In W. M. Reynolds, \& G. E. Miller (Eds.). Handbook of psychology (pp. 122). Hoboken, NJ: Wiley.

Russell, S. L. (2012). Individual-and classroom-level social support and classroom behavior in middle school, (Unpublished doctoral dissertation). University of Maryland.

Schunk, D. H., \& Meece, J. L. (Eds.). (1992). Student perceptions in the classroom. Hillsdale, NJ: Erlbaum.

Shaughnessy, M. F. (1991). The supportive educational environment for creativity. ERIC Digest, ED360080.

Shimahara, N. K. (1998). Politics of classroom life: Classroom management in international perspective. New York: Garland Publishing. 
Sümbuloglu, K., \& Akdag, B. (2009). Ileri biyoistatistiksel yöntemler (Advanced Biostatistical methods). Ankara: Hatipoğlu.

Sümer, N. (2000). Yapısal eşitlik modelleri: Temel kavramlar ve örnek uygulamalar (Structural equality models: Basic terms and representative applications). Türk Psikoloji Yazılarl, (3)6. 49-73.

Şeker, H., \& Gençdoğan, B. (2014). Psikolojide ve eğitimde ölçme aracı geliştirme (Developing measurement instruments in psychology and education.) Ankara: Nobel.

Şimşek, Ö. F. (2007). Yapısal eşitlik modellemesine giriş: Temel ilkeler ve LISREL Uygulamalarl (Access to Structural Equality Models: Basic Terms and LISREL Applications). İstanbul: Ekinoks.

Talton, E. L., \& Simpson, R. D. (1987). Relationships of attitude toward classroom environment with attitude toward and achievement in science among tenth grade biology students. Journal of research in Science Teaching, 24(6), 507-525. http://dx.doi.org/10.1002/tea.3660240602.

Trezise, K., \& Reeve, R. A. (2014). Cognition-emotion interactions: Patterns of change and implications for math problem solving. Frontiers in Psychology, 5, 840. http://dx.doi.org/10.3389/fpsyg.2014.00840.

Turner, J. C., Midgley, C., Meyer, D. K., Gheen, M., Anderman, E. M., Kang, Y., \& Patrick, H. (2002). The classroom environment and students' reports of avoidance strategies in mathematics: A multimethod study. Journal of Educational Psychology, 94(1), 88-106. http://dx.doi.org/10.1037//0022-0663.94.1.88.

Vieira A. L. (2011). Preparation of the analysis. Interactive LISREL in practice. London: Springer.

Walberg, H. J., \& Haertel, G. D. (1980). Validity and use of educational environment assessments. Studies in Educational Evaluation, 6(3), 225-238.

Wilson-Fleming, L., \& Wilson-Younger, D. (2012). Positive classroom environments=Positive academic results. ERIC Digest, ED536465.

Young, J. (2014). Encouragement in the classroom: How do I help students stay positive and focused? Alexandria, VA: ASCD. 